\title{
Investigation of Antiproliferative Effects of Home-Made and Commercial Apple Vinegars on Myeloma Cells
}

\author{
Muhammet Mükerrem Kaya ${ }^{1, a}$, Soner Tutun ${ }^{2, b}$, Melike Sultan Usluerr,c,*, Hidayet Tutun ${ }^{1, d}$ \\ ${ }^{I}$ Department of Pharmacology and Toxicology, Faculty of Veterinary Medicine, Burdur Mehmet Akif Ersoy University, Burdur, Turkey \\ ${ }^{2}$ Department of Food Hygiene and Technology, Faculty of Veterinary Medicine, Burdur Mehmet Akif Ersoy University, Burdur, Turkey
}

*Corresponding author

\begin{tabular}{l|l}
\hline ART ICLE INFO & A B S T R A C T \\
\hline & Vinegar is an aqueous food product made by a succession of yeast and acetic acid bacteria activities
\end{tabular}

Research Article from fruits that contain high carbohydrates such as apples and grapes. Vinegar has been used as a dietary spice and natural remedy since ancient times due to its therapeutic properties including

Received : 28/04/2021

Accepted : 09/11/2021 antimicrobial, antidiabetic, and anticancer activities. It has been shown that some bioactive compounds exhibiting antioxidant activity in vinegars lead to anticancer activity. The aim of the present study was to investigate antiproliferative effect of commercial and home-made apple vinegars in native and neutralized form on myeloma cells. In order to neutralize the vinegars, sodium hydroxide $(\mathrm{NaOH})$ was used. A serial two-fold dilutions of the vinegars $(50 \%, 25 \%, 12.5 \%, 6.25 \%$, $3.12 \%, 1.56 \%, 0.78 \%, 0.39 \%)$ prepared with cell medium were treated to the cells. The MTT (3-(4.5Dimethylthiazol-2-yl)-2.5-Diphenyltetrazolium Bromide) assay was used to determine the cellular

Keywords:

Antiproliferative activity Apple

Myeloma

Vinegar

Home-made viability in the cells treated with the vinegars. In this study, while commercial vinegar possessed a stronger antiproliferative activity than home-made vinegar, all native vinegars possessed stronger antiproliferative effect than neutralized vinegars. Interestingly, when home-made vinegar (both native and neutralized) concentrations were from 6.25 to $1.56 \%$, the cell viability increased. Apple vinegar exhibited antiproliferative activity on myeloma cells; however, further studies are required to clarify the mechanisms underlying this activity.

Türk Tarım - Gıda Bilim Ve Teknoloji Dergisi, 9(12): 2173-2178, 2021

\section{Ev Yapımı Elma Sirkesi ve Ticari Elma Sirkesinin Miyeloma Hücreleri Üzerine Antiproliferatif Etkisinin Araştırılması}

\begin{tabular}{|c|c|}
\hline M A K A L E B İ L G İ S İ & Ö Z \\
\hline $\begin{array}{l}\text { Anahtar Kelimeler: } \\
\text { Antiproliferatif etki } \\
\text { Elma } \\
\text { Miyeloma } \\
\text { Sirke } \\
\text { Ev yapımı }\end{array}$ & 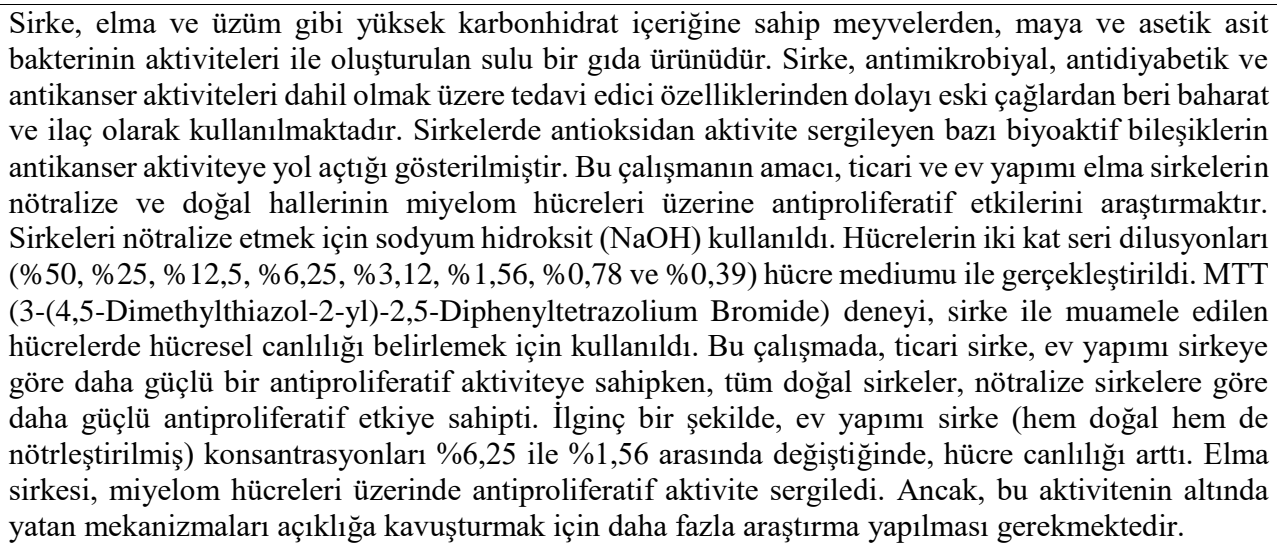 \\
\hline
\end{tabular}




\section{Introduction}

Multiple myeloma (MM) is a type of cancer formed by malignant B-cell neoplasm characterized by uncontrolled growth of mutated plasma cells within the bone marrow. MM begins as monoclonal gammopathy of undetermined significance (MGUS) which is an abnormal protein in blood (Bianchi and Munshi, 2015). It progresses to smoldering (asymptomatic) myeloma and finally becomes overt (symptomatic) myeloma (Fairfield et al., 2016). The patients with MM may suffer from bone pain or exhibit nonspecific symptoms, such as nausea, vomiting, malaise, weakness, recurrent infections, and weight loss (Gerecke et al., 2016; Michels et al., 2017). According to International Agency for Research on Cancer (IARC), 36\% of new cancer cases were detected in people over the age of 70 in 2018, and the prevalence of the cancer is expected to increase by more than twice the current number by 2040 (IARC, 2020). According to World Cancer Research Fund (WCRF), there were an estimated 18 million cancer cases around the world in 2018, of these cases 159.985 were MM (WCRF, 2018). Multiple myeloma accounts for $10 \%$ of all hematologic cancers. $85 \%$ of patients diagnosed with MM are older than 65 years old (Michels et al., 2017).

Complementary and Alternative Medicine (CAM) is a group of health care systems and practices that are not considered to be part of standard medical care (Garland et al., 2013). CAM has been recognized as a worldwide phenomenon among cancer patients. Many cancer patients have turned to CAMs as alternative ways to treat the cancer or lessen side-effects and toxicity of chemotherapy or radiation (Buckner et al., 2018). While the rate of using CAM treatment has reached $63 \%$ in some parts of the USA, this rate has reached 35\% in Europe (Berretta et al., 2017). It has been reported that substances such as Echinacea, evening primrose oil (Oenothera biennis), Gingko biloba, milk thistle (Silybum marianum), garlic (Allium sativum), ginseng (Panax ginseng), Gingko biloba and St John's wort (Hypericum perforatum) are among the most commonly used natural substances for cancer treatment (Gratus et al., 2009; Tutun et al., 2020).

Vinegar can be made from any fermentable carbohydrate source such as apple, grape, pear and melon by a two-stage fermentation, first alcoholic and then acetous. Vinegar contains acetic acid, water and trace amounts of other chemicals including vitamins, mineral salts, amino acids, polyphenolic compounds (e.g., gallic acid, catechin, caffeic acid, ferulic acid) and non-volatile organic acids (e.g., tartaric, citric, malic, lactic) (Kahraman et al., 2021, 2022; Luzón-Quintana et al., 2021). The amounts of acetic acid and trace elements vary according to the production processes of vinegar and the type of material used in the production (Xia et al., 2020). Vinegar has been used in the treatment of numerous disorders such as wound, inflammations, cough, ulcers, and infectious diseases for a long time in traditional medicine (Johnston and Gaas, 2006; Chen et al., 2016). Previous studies have been shown that vinegar has antimicrobial (Sengun and Karapinar, 2005), antioxidant, antiobesity (Halima et al., 2018) and antiproliferative activities (Nanda et al., 2004), and beneficial effects on atherosclerosis (Setorki et al., 2010), hypertension (Kondo at al., 2001), diabetes (Mitrou et al., 2015). Vinegar contains polyphenols reducing cancer risk via preventing the formation of $\mathrm{N}$-nitroso-compound which causes cancer in the body (Guo et al., 1997; Nishino et al., 2005; Johnston and Gaas, 2006). There is little evidence that apple vinegar can exert antiproliferative effects on cancer cells. Therefore, the aim of the present study was to investigate the antiproliferative effect of home-made and commercial apple vinegars in native and neutralized form on myeloma cells.

\section{Material and Methods}

\section{Preparation of Home-Made Apple Vinegar}

Apple vinegar sample used in the present study was made traditionally from apples via spontaneous fermentation. The apples called "Red delicious" were purchased from Isparta (Eğirdir distinct) province of Turkey. The procedure of vinegar production is given on the Figure 1. The vinegar samples were kept in the dark at $4^{\circ} \mathrm{C}$ until required (about 1 month). The vinegar samples were filtered through a filter paper before tests.

\section{Physicochemical Properties}

The $\mathrm{pH}$ values of the vinegars were measured with a $\mathrm{pH}$ meter (Sartorius Basic Meter PB-11). Determination of total acidity of the vinegars was performed by titrimetric method (Gao et al., 2017) and the results were expressed as acetic acid equivalent (g acetic acid /L vinegar sample).

\section{Cell Culture}

Myeloma (F0 ATCC CRL-1646) cell line was maintained in Dulbecco's Modified Eagle's Medium (DMEM) containing 10\% fetal bovine serum (FBS), $0.1 \%$ gentamicin, $1 \%$ sodium pyruvate and $2 \%$ L-glutamine in a cell incubator (Steri-Cycle i160, Thermo Scientific) at $37^{\circ} \mathrm{C}$, in $5 \% \mathrm{CO}_{2}$ and $95 \%$ relative humidity.

\section{Cell Viability Test}

The cells were seeded in 96-well plates $\left(3 \times 10^{5}\right.$ cells $/ \mathrm{mL}$ ) and cultured in $5 \% \mathrm{CO}_{2}$ incubator at $37^{\circ} \mathrm{C}$ overnight. Commercial apple vinegar was purchased at a local market in Burdur province of Turkey. To determine whether the antiproliferative effect was due to the acid content of the vinegars, both vinegar samples were neutralized with $1 \mathrm{~N} \mathrm{NaOH}$. Two-fold serial dilutions $(50 \%, 25 \%, 12.5 \%, 6.25 \%, 3.12 \%, 1.56 \%, 0.78 \%, 0.39 \%)$ of both the neutralized and native forms of the vinegars were prepared with DMEM (Dulbecco's Modified Eagle's). DMEM was used as negative control and $0.1 \%$ Triton X-100 was used as positive control. MTT (3-(4,5dimethylthiazol-2-yl)-2,5-diphenyl tetrazolium bromide, Sigma) test was used to assess the effect of the vinegars on viability of myeloma cells. After $24 \mathrm{~h}$ of treatment, the medium was removed from the plates. The MTT was dissolved in PBS to prepare stock solution $(5 \mathrm{mg} / \mathrm{ml})$. MTT was added to each well at a final concentration of 0.5 $\mathrm{mg} / \mathrm{ml}$ and then the plates were incubated for $3 \mathrm{~h}$ in dark at $37^{\circ} \mathrm{C}$. MTT solution was removed from the wells and 150 $\mu \mathrm{l}$ dimethyl sulfoxide was added to each well to dissolve the formazan crystals formed. The plate was kept on a horizontal shaker (Thermo scientific) for 30 minutes. Absorbances were measured at $570 \mathrm{~nm}$ with a microplate spectrophotometer (Multiskan Go, Thermo Scientific). The half maximal inhibitory concentration $\left(\mathrm{IC}_{50}\right)$ values were calculated as previously described (Tutun et al., 2020). 


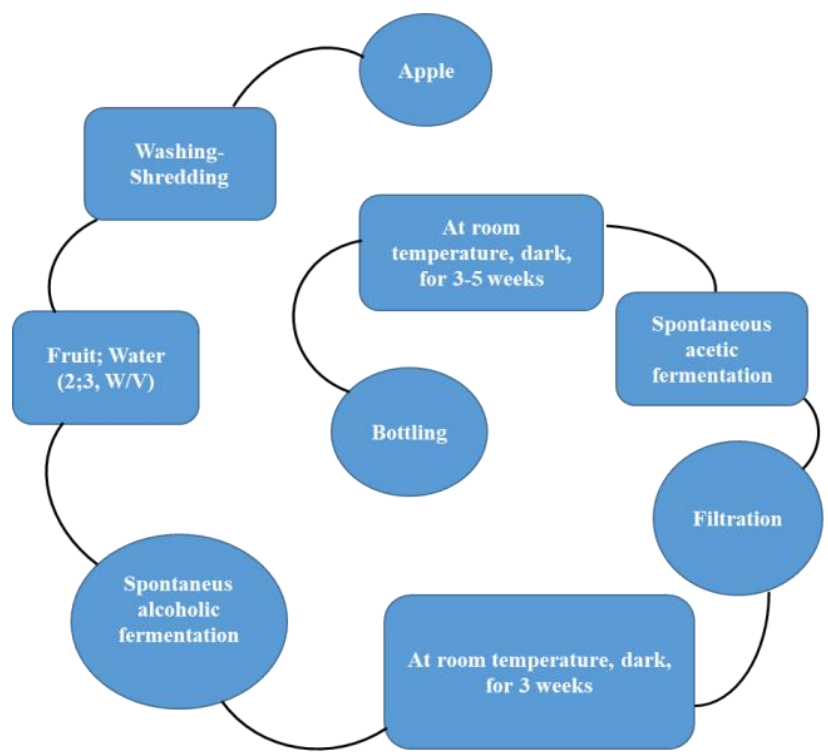

Figure 1. Home-made apple vinegar production scheme

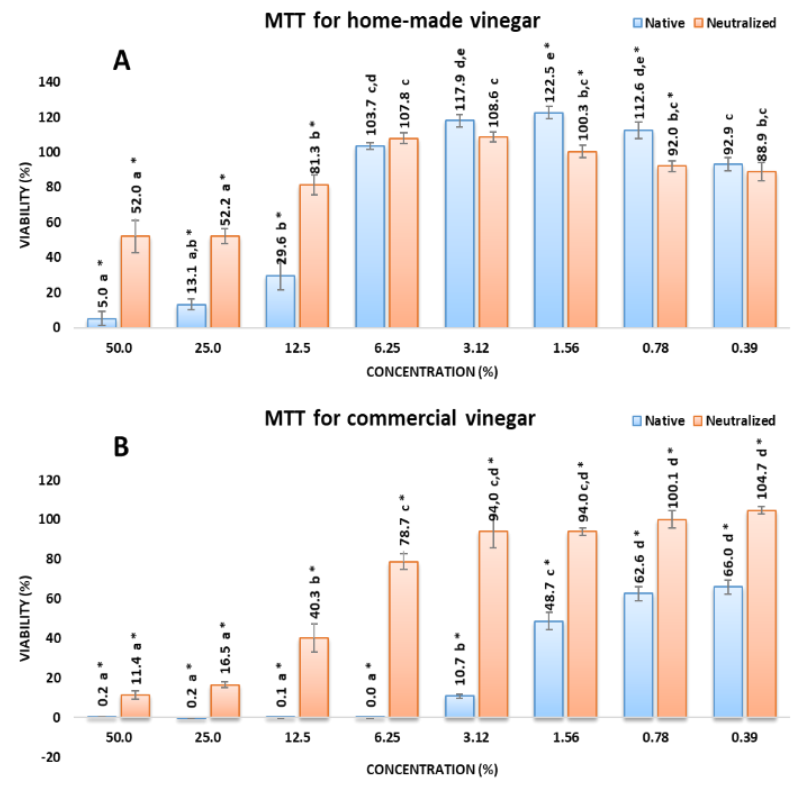

Figure 2. The cell viability in myeloma cells by using MTT assay. (A) Viability of the cells treated with homemade apple vinegars (both native and neutralized) for 24 h. (B) Viability of the cells treated with commercial apple vinegars (native and neutralized). Values are expressed as means \pm SD. Small letters (a,b,c,d,e) and asterisk (*) indicate the subsets determined via Tukey pairwise comparison based on dosages and types of vinegar, respectively ( $\mathrm{p}$-value<0.05).

\section{Statistical Analysis}

Each concentration of the vinegars on viability of the cell was evaluated in triplicate. $\mathrm{IC}_{50}$ values were calculated using the Microsoft Excel program. Antiproliferative performances of vinegars were compared via One-way MANOVA. Tukey's test was chosen for post-hoc pairwise comparisons and to determine homogeneous subsets. IBM SPSS Statistics 22 was used.

\section{Results}

In this study, the $\mathrm{pH}$ values of home-made apple vinegar and commercial apple vinegar were 3.18 and 2.86, respectively. While the total acidity of home-made was 10.2 grams acetic acid /L sample, the total acidity commercial vinegar was $40.2 \mathrm{~g} / \mathrm{L} .4 .4 \mathrm{ml}$ and $1.9 \mathrm{ml}$ of $1 \mathrm{~N} \mathrm{NaOH}$ were used to neutralize $10 \mathrm{ml}$ of commercial vinegar and homemade vinegar, respectively.

$\mathrm{IC}_{50}$ values for native and neutralized commercial apple vinegars were $0.84 \%$ and $9.98 \%$, respectively. $\mathrm{IC}_{50}$ values for native and neutralized home-made apple vinegars were $12.27 \%$ and $46.78 \%$, respectively. There was a statistically significant difference in antiproliferative performance of vinegars based on dosage, $\mathrm{F}=34.571, \mathrm{p}<.0001$; Wilk's $\Lambda$ $=0$. Native commercial vinegar possessed a stronger antiproliferative activity than home-made vinegar (both native and neutralized) and neutralized commercial apple vinegar (Figure 2). The antiproliferative activity of neutralized vinegars on myeloma cells were significantly less compared to native vinegars. While the antiproliferative effect of native commercial vinegar increased in a dosedependent manner, no linear dose response was observed in both native and neutralized home-made vinegars. The homemade vinegar exerted a markedly different effect on the viability of myeloma cells. A weak inhibition in growth of myeloma cells was observed at high concentration of neutralized home-made vinegar. Interestingly, when homemade vinegar concentrations were between 6.25 and $0.78 \%$ for native and between 6.25 and $1.56 \%$ for neutralized, the cell viability increased compared to the negative control (DMEM treated only). The findings of this study indicated that the antiproliferative effect of home-made vinegar was content and dose-dependent.

\section{Discussion}

Cancer is the leading cause of death globally, with an estimated 9.6 million deaths in 2018 and responsible for approximately 1 in every 6 deaths worldwide (WHO, 2020). There are a large number of researches indicating that some alternative therapies are safe and effective when used with chemotherapy (Adams and Jewels, 2007; Xu et al., 2007; Bilir et al., 2018; Aktaş et al., 2020). Due to their numerous pharmacological and biological activities, several natural products derived from plants have been used for treatment and prevention of human disorders for thousands of years (Demirtaş et al., 2019; Fu et al., 2019). The current interest focuses on determination of the antiproliferative effects of these natural products on cancer cells (Gill et al., 2005; Tavakoli et al., 2012; Huang et al., 2019; Tutun et al., 2020). Vinegar, which is a plant-based product, has been widely consumed for treating several human disorders such as hyperglycemia, hyperlipidemia, cancer and oxidative stress due to their bioactive substances and various beneficial effects on health (Gheflati et al., 2019; Mohamad et al., 2019; Ousaaid et al., 2020).

In this study, $\mathrm{pH}$ values of commercial (2.86) and home-made (3.18) vinegars were in line with previous studies (Gerbi et al., 1998; Akbaş and Cabaroğlu, 2010; Sung et al., 2014). Total acidity is an important indicator for assessing the quality of vinegar (Zhao et al., 2018). The commercial vinegar $(40.2 \mathrm{~g} / \mathrm{L})$, with the exception of 
home-made vinegar $(10.2 \mathrm{~g} / \mathrm{L})$, complied with regulatory limits for total acidity (Turkey National Standard: TS 1880 EN 13188:2003, total acidity $\geq 40 \mathrm{~g} / \mathrm{L})$.

Apple vinegars have high phenols, proteins and flavonoids which show potent antioxidant activity and anticancer effect against several cancer cells (Boyer and Liu 2004; Budak et al., 2011; Batra and Sharma, 2013; Anantharaju et al., 2016). Many studies suggest that the antiproliferative activity in cancer cells could be related to the antioxidant properties of the tested compounds ( $\mathrm{Li}$ et al., 2007; Grigalius and Petrikaite, 2017). Vinegars obtained from sugar cane (Mimura et al., 2004), Kurosu (Nanda et al., 2004), Izumi (Baba et al., 2013) have been shown anticancer activity by obstructing the differentiation of human cancer cells via programmed necrosis and promotion of apoptosis (Ali et al., 2017). A paper has been indicated that apple vinegar exhibited antiproliferative effect on colon cancer cell line (HT-19) (Dubey et al., 2019). In this study, both native vinegars inhibited the growth of myeloma cells. Commercial native vinegar has been found to be very strong antiproliferative activity, compared home-made native vinegar. Acetic acid, which is a constituent of vinegar, has been shown to have anticancer effects via a mechanism involving oxidative stress leading to apoptosis in the cancer cells and these effects of acetic acid depend on the concentration of the chemical (Okabe et al., 2014; Terasaki et al., 2018). Native commercial vinegar demonstrated a higher antiproliferative effect than native home-made vinegar, which can be attributed to the presence of lower organic acid content of the latter. There was a decrease in the antiproliferative activity of both neutralized home-made and commercial vinegars compared to native vinegars. Commercial neutralized vinegar showed a stronger antiproliferative effect than home-made neutralized vinegar. Interestingly, home-made vinegar (both native and neutralized) increased cell growth compared to control wells in the dose range of 6.25 to $1.56 \%$, while decreasing cell growth at high and low doses. Apple vinegars contain various bioactive components such as polyphenols (Budak et al., 2015; Bakir et al., 2016) showing anticancer activity (Abdal Dayem et al., 2016). The difference in antiproliferative activity between commercial and homemade vinegars may be attributed to the difference in vinegar composition, which is the result of many different variables in the production process (Morgan and Mosawy, 2016).

\section{Conclusion}

In this study, commercial and home-made apple vinegars in native and neutralized form showed antiproliferative effect on myeloma cells in a dosedependent manner. The activity may be attributed to their bioactive components that have anticancer activity.

\section{Conflict of Interest}

The authors declare that there is no conflict of interest.

\section{References}

Abdal Dayem A, Choi HY, Yang GM, Kim K, Saha SK, Cho SG. 2016. The Anti-Cancer Effect of Polyphenols against Breast Cancer and Cancer Stem Cells: Molecular Mechanisms. Nutrients, 8: 581. doi: 10.3390/nu8090581.
Adams M, Jewell AP. 2007. The Use of Complementary and Alternative Medicine by Cancer Patients. International Seminars in Surgical Oncology, 4: 1-7. doi: 10.1186/14777800-4-10.

Akbaş M, Cabaroğlu T. 2010. Ülkemizde Üretilen Bazı Üzüm Sirkelerinin Bileşimleri ve Gıda Mevzuatına Uygunlukları Üzerine Bir Araştırma. Gıda, 35: 183-188.

Aktaş İ, Özmen Ö, Tutun H, Yalçın A, Türk A. 2020. Artemisinin Attenuates Doxorubicin Induced Cardiotoxicity and Hepatotoxicity in Rats. Biotechnic and Histochemistry. 95: 121-128. doi: 10.1080/10520295.2019.1647457.

Ali Z, Wang Z, Amir RM, Younas S, Wali A, Adowa N, Ayim I. 2016. Potential Uses of Vinegar as A Medicine and Related in vivo Mechanisms. International Journal for Vitamin and Nutrition Research, 86: 127-151. doi: 10.1024/03009831/a000440.

Anantharaju PG, Gowda PC, Vimalambike MG, Madhunapantula SV. 2016. An Overview on the Role of Dietary Phenolics for The Treatment of Cancers. Nutrition Journal, 15: 99. doi: 10.1186/s12937-016-0217-2.

Baba N, Higashi Y, Kanekura T. 2013. Japanese Black Vinegar "Izumi" Inhibits the Proliferation of Human Squamous Cell Carcinoma Cells via Necroptosis. Nutrition and Cancer, 65: 1093-1097. doi: 10.1080/01635581.2013.815234.

Bakır S, Toydemir G, Boyacioglu D, Beekwilder J, Capanoglu E. 2016. Fruit Antioxidants during Vinegar Processing: Changes in Content and in vitro Bio-Accessibility. International Journal of Molecular Sciences, 17: 1658. doi: 10.3390/ijms 17101658 .

Batra P, Sharma AK. 2013. Anti-Cancer Potential of Flavonoids: Recent Trends and Future Perspectives. 3 Biotech, 3: 439459. doi: 10.1007/s13205-013-0117-5.

Berretta M, Della Pepa C, Tralongo P, Fulvi A, Martellotta F, Lleshi A, Nasti G, Fisichella R, Romano C, De Divitiis C, Taibi R, Fiorica F, Di Francia R, Di Mari A, Del Pup L, Crispo A, De Paoli P, Santorelli A, Quagliariello V, Iaffaioli RV, Tirelli U, Facchini G. 2017. Use of Complementary and Alternative Medicine (CAM) in cancer patients: An Italian Multicenter Survey. Oncotarget, 8: 24401-24414. doi: 10.18632/oncotarget.14224.

Bianchi G, Munshi NC. 2015. Pathogenesis Beyond the Cancer Clone (S) in Multiple Myeloma. Blood, 125(20): 3049-3058. doi: 10.1182/blood-2014-11-568881.

Bilir EK, Tutun H, Sevin S, Kismali G, Yarsan E. 2018. Cytotoxic Effects of Rhododendron ponticum L. Extract on Prostate Carcinoma and Adenocarcinoma Cell Line (DU145, PC3). Kafkas Üniversitesi Veteriner Fakültesi Dergisi, 24: 451-457. doi: 10.9775/kvfd.2017.19219.

Boyer J, Liu RH. 2004. Apple Phytochemicals and Their Health Benefits. Nutrition Journal, 3: 5. doi: 10.1186/1475-2891-3-5.

Buckner CA, Lafrenie RM, Dénommée JA, Caswell JM, Want DA. 2018. Complementary and Alternative Medicine Use in Patients Before and After a Cancer Diagnosis. Current Oncology, 25: 275-281. doi: 10.3747/co.25.3884.

Budak NH, Kumbul Doguc D, Savas CM, Seydim AC, Kok Tas T, Ciris MI, Guzel-Seydim ZB. 2011. Effects of Apple Cider Vinegars Produced with Different Techniques on Blood Lipids in High-Cholesterol-Fed Rats. Journal of Agricultural and Food Chemistry, 59: 6638-6644. doi: 10.1021/jf104912h.

Budak NH, Ozçelik F, Güzel-Seydim ZB. 2015. Antioxidant Activity and Phenolic Content of Apple Cider. Turkish Journal of Agriculture - Food Science and Technology, 3: 356-360. doi:10.24925/turjaf.v3i6.356-360.265.

Chen H, Chen T, Giudici P, Chen F. 2016. Vinegar Functions on Health: Constituents, Sources, and Formation Mechanisms. Comprehensive Reviews in Food Science and Food Safety, 15: 1124-1138. doi./10.1111/1541-4337.12228.

Demirtaş A, Ozturk H, Sudagidan M, Keyvan E, Yavuz O, Gulay OY, Musa SAA. 2019. Effects of Commercial Aldehydes from Green Leaf Volatiles (Green Odour) on Rumen Microbial Population and Fermentation Profile in An Artificial Rumen (Rusitec). Anaerobe, 55: 83-92. doi: 10.1016/j.anaerobe.2018.11.001. 
Dubey P, Ramaswamy R, Chitra V, Sumithra M, Gayathiri K. 2019. Evaluation of Antioxidant, Antiproliferative and Chemoprophylactic Effect of Apple Cider Vinegar against Colon Cancer Cell Lines. International Research Journal of Pharmacy, 10: 105-109. doi: 10.7897/2230-8407.100387.

Fairfield H, Falank C, Avery L, Reagan MR. 2016. Multiple Myeloma in The Marrow: Pathogenesis and Treatments. Annals of the New York Academy of Sciences, 1364: 32-51. doi: 10.1111/nyas.13038.

Fu B, Wang N, Tan HY, Li S, Cheung F, Feng Y. 2018. MultiComponent Herbal Products in the Prevention and Treatment of Chemotherapy-Associated Toxicity and Side Effects: A Review on Experimental and Clinical Evidences. Frontiers in Pharmacology, 9: 1394. doi: 10.3389/fphar.2018.01394.

Gao Y, Jo Y, Chung N, Gu SY, Jeong YJ, Kwon JH. 2017. Physicochemical Qualities and Flavor Patterns of Traditional Chinese Vinegars Manufactured by Different Fermentation Methods and Aging Periods. Preventive Nutrition and Food Science, 22:30-36. doi: 10.3746/pnf.2017.22.1.30.

Garland SN, Valentine D, Desai K, Li S, Langer C, Evans T, Mao JJ. 2013. Complementary and Alternative Medicine Use and Benefit Finding among Cancer Patients. Journal of Alternative and Complementary Medicine, 19: 876-81. doi: 10.1089/acm.2012.0964.

Gerbi V, Zeppa G, Beltramo R, Carnacini A, Antonelli A. 1998. Characterisation of White Vinegars of Different Sources with Artificial Neural Networks. Journal of the Science of Food and Agriculture, 78: 417-422. doi: 10.1002/(SICI)10970010(199811)78:3<417::AID-JSFA134>3.0.CO;2-8.

Gerecke C, Fuhrmann S, Strifler S, Schmidt-Hieber M, Einsele H, Knop S. 2016. The Diagnosis and Treatment of Multiple Myeloma. Deutsches Ärzteblatt International, 113: 470-476. doi: 10.3238/arztebl.2016.0470.

Gheflati A, Bashiri R, Ghadiri-Anari A, Reza JZ, Kord MT, Nadjarzadeh A. 2019. The Effect of Apple Vinegar Consumption on Glycemic Indices, Blood Pressure, Oxidative Stress, and Homocysteine in Patients with Type 2 Diabetes and Dyslipidemia: A Randomized Controlled Clinical Trial. Clinical Nutrition ESPEN, 33: 132-138. doi: 10.1016/j.clnesp.2019.06.006.

Gill CI, Boyd A, McDermott E, McCann M, Servili M, Selvaggini R, Taticchi A, Esposto S, Montedoro G, McGlynn H, Rowland I. 2005. Potential Anti-Cancer Effects of Virgin Olive Oil Phenols on Colorectal Carcinogenesis Models in vitro. International Journal of Cancer, 117: 1-7. doi: 10.1002/ijc.21083.

Gratus C, Damery S, Wilson S, Warmington S, Routledge P, Grieve R, Steven N, Jones JE, Greenfield S. 2009. The Use of Herbal Medicines by People with Cancer in the UK: A Systematic Review of the Literature. QJM: An International Journal of Medicine, 102: 831-842. doi: 10.1093/qjmed/hcp137.

Grigalius I, Petrikaite V. 2017. Relationship Between Antioxidant and Anticancer Activity of Trihydroxyflavones. Molecules, 22: 2169. doi: 10.3390/molecules22122169.

Guo XK, Wang TJ, Gu JF. 1997. Effect of Esophageal Cancerand Stomach Cancer-Preventing Vinegar on N-nitrosoproline Formation in The Human Body. World Journal of Gastroenterology, 3: 269-270. doi: 10.3748/wjg.v3.i4.269.

Halima BH, Sonia G, Sarra K, Houda BJ, Fethi BS, Abdallah A. 2018. Apple Cider Vinegar Attenuates Oxidative Stress and Reduces the Risk of Obesity in High-Fat-Fed Male Wistar Rats. Journal of Medicinal Food, 21: 70-80. doi: 10.1089/jmf.2017.0039.

Huang WC, Chang MS, Huang SY, Tsai CJ, Kuo PH, Chang HW, Huang ST, Kuo CL, Lee SL, Kao MC. 2019. Chinese Herbal Medicine Ganoderma tsugae Displays Potential Anti-Cancer Efficacy on Metastatic Prostate Cancer Cells. International Journal of Molecular Sciences, 20: 4418. doi: 10.3390/ijms20184418.
IARC, 2020. International Agency for Research on Cancer. Cancer Tomorrow Available from: https://gco.iarc.fr/tomorrow/graphicline?type=0\&type_sex $=$ $0 \&$ mode $=$ population $\&$ se $x=0 \&$ populations $=900 \&$ cancers $=35$ \&age_group $=65 \% 2 \mathrm{~B} \&$ apc_male $=0 \&$ apc_female $=0 \&$ single unit $=500000 \&$ print $=0$; [Accessed 20 October 2020].

Johnston CS, Gaas CA. 2006. Vinegar: Medicinal Uses and Antiglycemic Effect. The Medscape Journal of Medicine, 8: 61. PMID: 16926800.

Kahraman HA, Tutun H, Kaya MM, Tutun S, Usluer MS, Rugji J, Yurdakul O. 2021. Total phenolic content, antiradical, antimicrobial and antibiofilm properties of grape and apple vinegar. Journal of Advances in VetBio Science and Techniques, 6(2): 150-158. doi: 10.31797/vetbio.960155

Kahraman HA, Tutun H, Keyvan E, Balkan BM. 2022. Investigation of Chemical, Antibacterial and Antiradical Properties of Home-made Apple and Grape Vinegars. Ankara Üniversitesi Veteriner Fakültesi Dergisi. doi: 10.33988/auvfd.865309

Kondo S, Tayama K, Tsukamoto Y, Ikeda K, Yamori Y. 2001. Antihypertensive Effects of Acetic Acid and Vinegar on Spontaneously Hypertensive Rats. Bioscience Biotechnology and Biochemistry, 65: 2690-4. doi: 10.1271/bbb.65.2690.

Li WY, Chan SW, Guo DJ, Yu PHF. 2007. Correlation Between Antioxidative Power and Anticancer Activity in Herbs from Traditional Chinese Medicine Formulae with Anticancer Therapeutic Effect. Pharmaceutical Biology, 45: 541-546. doi: $10.1080 / 13880200701498879$.

Luzón-Quintana LM, Castro R, Durán-Guerrero E. 2021. Biotechnological Processes in Fruit Vinegar Production. Foods, 10: 945. doi:org/10.3390/foods10050945.

Michels TC, Petersen KE. 2017. Multiple Myeloma: Diagnosis and Treatment. American Family Physician, 95: 373-383. PMID: 28318212.

Mimura A, Suzuki Y, Toshima Y, Yazaki SI, Ohtsuki T, Ui S, Hyodoh F. 2004. Induction of Apoptosis in Human Leukemia Cells by Naturally Fermented Sugar Cane Vinegar (Kibizu) of Amami Ohshima Island. Biofactors, 22: 93-7. doi: 10.1002/biof.5520220118.

Mitrou P, Petsiou E, Papakonstantinou E, Maratou E, Lambadiari V, Dimitriadis P, Spanoudi F, Raptis SA, Dimitriadis G. 2015. Vinegar Consumption Increases Insulin-Stimulated Glucose Uptake by the Forearm Muscle in Humans with Type 2 Diabetes. Journal of Diabetes Research, 175204 doi: $10.1155 / 2015 / 175204$.

Mohamad NE, Abu N, Yeap SK, Lim KL, Romli MF, Sharifuddin SA, Long K, Alitheen NB. 2019. Apoptosis and Metastasis Inhibitory Potential of Pineapple Vinegar against Mouse Mammary Gland Cells in vitro and in vivo. Nutrition and Metabolism, 16: 49. doi: 10.1186/s12986-019-0380-5.

Morgan J, Mosawy S. 2016. The Potential of Apple Cider Vinegar in The Management of Type 2 Diabetes. International Journal of Diabetes Research, 5: 129-134. doi: 10.5923/j.diabetes.20160506.02.

Nanda K, Miyoshi N, Nakamura Y, Shimoji Y, Tamura Y, Nishikawa Y, Uenekai K, Kohno H, Tanaka, T. 2004. Extract of Vinegar" Kurosu" from Unpolished Rice Inhibits the Proliferation of Human Cancer Cells. Journal of experimental and clinical cancer research, 23: 69-76. PMID: 15149153.

Nishino H, Murakoshi M, Mou XY, Wada S, Masuda M, Ohsaka Y, Satomi Y, Jinno K. 2005. Cancer Prevention by Phytochemicals. Oncology, 69: 38-40. doi: $10.1159 / 000086631$.

Okabe S, Okamoto T, Zhao CM, Chen D, Matsui H. 2014. Acetic Acid Induces Cell Death: An in vitro Study Using Normal Rat Gastric Mucosal Cell Line and Rat and Human Gastric Cancer and Mesothelioma Cell Lines. Journal of Gastroenterology and Hepatology, 29: 65-69. doi: 10.1111/jgh.12775. 
Ousaaid D, Laaroussi H, Bakour M, ElGhouizi A, Aboulghazi A, Lyoussi B, ElArabi I. 2020. Beneficial Effects of Apple Vinegar on Hyperglycemia and Hyperlipidemia in Hypercaloric-Fed Rats. Journal of Diabetes Research, 2020: 3. doi: 10.1155/2020/9284987.

Sengun IY, Karapinar M. 2005. Effectiveness of Household Natural Sanitizers in The Elimination of Salmonella typhimurium on Rocket (Eruca sativa Miller) and Spring Onion (Allium cepa L.). International Journal of Food Microbiology, 98: 319-323. doi: 10.1016/j.ijfoodmicro.2004.07.011.

Setorki M, Asgary S, Eidi A, Rohani AH, Khazaei M. 2010. Acute Effects of Vinegar Intake on Some Biochemical Risk Factors of Atherosclerosis in Hypercholesterolemic Rabbits. Lipids in Health and Disease, 9:10. doi: 10.1186/1476-511X9-10.

Sung NH, Woo SM, Kwon JH, Yeo SH, Jeong YJ. 2014. Quality Characteristics of High Acidity Apple Vinegar Manufactured Using Two Stage Fermentation. Journal of the Korean Society of Food Science and Nutrition, 43: 877-883. doi: 10.3746/jkfn.2014.43.6.877.

Tavakoli J, Miar S, Majid Zadehzare M, Akbari H. 2012. Evaluation of Effectiveness of Herbal Medication in Cancer Care: A Review Study. Iranian Journal of Cancer Prevention, 5: $144-156$.

Terasaki M, Ito H, Kurokawa H, Tamura M, Okabe S, Matsui H, Hyodo I. 2018. Acetic Acid is an Oxidative Stressor in Gastric Cancer Cells. Journal of Clinical Biochemistry and Nutrition, 63: 36-41. doi: 10.3164/jcbn.17-49.
Tutun S, Kaya MM, Usluer MS, Tutun H. 2020. Investigation of Antiproliferative Effects of Hypericum perforatum Oil on Myeloma Cells. Mehmet Akif Ersoy Üniversitesi Veteriner Fakültesi Dergisi, 5: 79-82. doi: 10.24880/maeuvfd.728975.

WCRF, 2018. World Cancer Research Fund. Worldwide cancer data. Available from: https://www.wcrf.org/ dietandcancer/cancer-trends/worldwide-cancer-data [Accessed 01 October 2020].

WHO, 2020 World Health Organization. Cancer. Available from: https://www.who.int/news-room/fact-sheets/detail/cancer; [Accessed 07 October 2020].

Xia T, Zhang B, Duan W, Zhang J, Wang M. 2020. Nutrients and Bioactive Components from Vinegar: A Fermented and Functional Food. Journal of Functional Foods, 64: 103681. doi: 10.1016/j.jff.2019.103681.

Xu L, Lao LX, Ge A, Yu S, Li J, Mansky PJ. 2007. Chinese Herbal Medicine for Cancer Pain. Integrative Cancer Therapies, 6:208-234. doi: 10.1177/1534735407305705.

Zhao C, Xia T, Du P, Duan W, Zhang B, Zhang J, Zhu S, Zheng Y, Wang M, Yu Y. 2018. Chemical Composition and Antioxidant Characteristic of Traditional and Industrial Zhenjiang Aromatic Vinegars during The Aging Process. Molecules, 23: 2949. doi: 10.3390/molecules23112949. 